\title{
INFLUENCE OF AGE ON SWALLOWS OF A HIGHLY VISCOUS LIQUID BOLUS
}

\author{
Weslania Viviane NASCIMENTO, Carla Manfredi SANTOS, Rachel Aguiar CASSIANI \\ and Roberto Oliveira DANTAS
}

\begin{abstract}
Background - Swallow function has a decline with aging, mainly in those over 80 years old. In the population over 69 years, about $11 \%$ of subjects reported symptoms indicative of significant dysphagia. Objective - Our objective was to evaluate the hypothesis that older asymptomatic subjects before 80 years old have compensations to sustain a safe and efficient swallow, at least with swallows of liquid bolus. Method - We performed videofluoroscopic evaluation of swallows in 55 normal volunteers, a younger group with 33 subjects ( 16 men and 17 women) aged 19 to 55 years, mean 35.5 \pm 9.8 years, and an older group with 22 subjects (15 men and 7 women) aged 56 to 77 years, mean $64.8 \pm 6.8$ years. The subjects swallowed in duplicate $5 \mathrm{~mL}$ and $10 \mathrm{~mL}$ of liquid barium with a $\mathrm{pH}$ of 7.9 , density of $1.82 \mathrm{~g} / \mathrm{cm}^{3}$, and viscosity of $895 \mathrm{cp}$. Results - The mean duration of pharyngeal transit, pharyngeal clearance, upper esophageal sphincter opening, hyoid movement and oral-pharyngeal transit were longer in the younger group compared with the older group. The relation between pharyngeal clearance duration and hyoid movement duration was similar in younger and older subjects, for $5 \mathrm{~mL}$ and $10 \mathrm{~mL}$ bolus volumes. Conclusion - On average, a highly viscous liquid bolus crosses the pharynx faster in older subjects (56-77 years old) than in younger subjects (19-55 years old), which suggested an adaptation to the aging process to maintain a safe swallow.
\end{abstract}

HEADINGS - Deglutition disorders. Pharynx. Age effect. Peristalsis. Viscosity.

\section{INTRODUCTION}

The aging process has influence on oral-pharyngeal transit duration during swallows ${ }^{(11,12,13,15,19)}$. Swallow function has a decline with aging in asymptomatic subjects, mainly over 80 years old, with some subjects having similar pharyngeal function as patients with dysphagia $^{(19)}$. In a population evaluation, $11.4 \%$ of subject ages 69-98 years reported symptoms indicative of dysphagia ${ }^{(10)}$.

The aging process causes an increase in frequency of dipper swallows, compared with tipper swallows ${ }^{(6)}$, a delay in triggering the pharyngeal phase ${ }^{(16)}$, a loss in muscle reserve involved with swallowing ${ }^{(17,18)}$, increase in frequency of laryngeal penetration during swallow $^{(21)}$, a delay in proximal esophageal response to wet swallows ${ }^{(4)}$ and, for liquid bolus, a longer pharyngeal flow, reduced upper esophageal sphincter (UES) opening, higher hypopharyngeal intrabolus pressure, reduced pharyngeal diameter, increased pharyngeal residues, reduced UES intrabolus pressure ${ }^{(19)}$, and loss of pharyngeal and supraglottic sensitivity ${ }^{(1,5,23)}$. However, most of these alterations were seen in patients over 80 years, or at least over 70 years. It is not know the swallowing response and compensation in asymptomatic subjects over 50 years but before
80 years old during swallows of a highly viscous liquid bolus. Previous investigations did not find loss on swallowing efficiency before 80 years, in the swallow index risk ${ }^{(19)}$ and in esophageal contraction amplitude ${ }^{(8,20)}$. Bolus pharyngeal transit time in older subjects is longer with swallows of $20 \mathrm{~mL}$ volume of liquid bolus, but not with swallows of $1 \mathrm{~mL}$ bolus volume $^{(15)}$,compared with younger subjects. Swallows of a non viscous bolus (water) cause an increase in the duration of pharyngeal transit and pharyngeal clearance in subjects older than 55 years $^{(2)}$.

The upper esophageal sphincter (UES) opening should occur during the superior-anterior movement of the hyoid. The hyoid movement must have a longer duration than the UES bolus transit, to avoid pharyngeal residues and the risk of aspiration. The proportion between pharyngeal transit and UES opening duration may be compromised by the aging process.

Our hypothesis is that older patients have compensations to sustain a safe swallow of a viscous liquid bolus. They will lose their functional reserve after 70 or 80 years ${ }^{(19)}$. Our objective in this investigation was to compare, by the videofluoroscopic method, the oral and pharyngeal transit of a highly viscous liquid bolus in younger (19-55 years old) and older (56-77 years old) healthy subjects. 


\section{METHOD}

Videofluoroscopic evaluation of swallows was performed in 55 asymptomatic volunteers, 31 men and 24 women, aged 19 to 77 years. This population was organized in two groups, a younger group with 33 subjects (16 men and 17 women) aged 19 to 55 years, mean $35.5 \pm 9.8$ years, 21 with ages below 40 years old, and an older group with 22 subjects ( 15 men and 7 women) aged 56 to 77 years, mean $64.8 \pm 6.8$ years, 6 with ages above 70 years old.

As there was only seven women in the older group we compared also the swallows of younger $(n=16$, ages: $19-52$ years, mean: $35.1 \pm 9.4$ years) and older $(n=15$, ages: $56-77$ years, mean: $64.7 \pm 6.8$ years) men, and younger $(n=17$, ages: $22-55$ years, mean: $36.4 \pm 10.2$ years) and older $(n=7$, ages: $56-72$ years, mean: $65.0 \pm 6.8$ years) women. None of the volunteers had dysphagia, gastroesophageal reflux symptoms, previous surgery of the head, neck, esophagus or stomach, neurologic diseases, or any kind of problem with the ingestion of liquid or solid foods. The study was approved by the Human Research Committee of the University Hospital of Ribeirão Preto. Written informed consent was given by all volunteers.

We used the radiologic instrument Arcomax Phillips model BV 300 (Veenpluis, The Netherlands), and the digital image processing system Ever Focus model EDSR 100 V1.2 (Taipei, Taiwan) with a DVR (Ever Focus) monitor, run at 60 frames/ second and a clock time that indicates digital time in seconds and the number of frames on each video frame. Each subject was studied while sitting in a chair, turned laterally to the image intensifier. Lateral images were obtained of the mouth, pharynx, and proximal esophagus. The subjects swallowed in duplicate $5 \mathrm{~mL}$ and $10 \mathrm{~mL}$ of liquid barium $(100 \%$ barium sulfate, Bariogel, Laboratory Cristália, Itapira SP, Brazil) with has a $\mathrm{pH}$ of 7.9 , density of $1.82 \mathrm{~g} / \mathrm{cm}^{3}$, and viscosity of 895 $\mathrm{cp}$, measured at $26^{\circ} \mathrm{C}$ with spindle rotation of $50 \mathrm{RPM}$. The viscosity was measured by a Brookfield rheometer (Brookfield Engineering Laboratories, Massachussets, USA).

We timed the following features: (1) onset of propulsive tongue tip movement at the maxillary incisors, (2) onset and end of the hyoid movement, (3) passage of the bolus head through the fauces, (4) passage of the bolus tail through the fauces, and (5) onset and offset of upper esophageal sphincter opening. From these timings we calculated the oral transit (tongue tip at incisors to passage of the bolus tail through the fauces), pharyngeal transit (bolus tail at fauces to closure of UES), pharyngeal clearance (bolus head at fauces to closure of UES), UES opening duration (time between onset and offset of UES opening), duration of hyoid movement (time between onset and end of the hyoid movement), oral-pharyngeal transit (tongue tip at incisors to offset of UES opening), and the relation between pharyngeal clearance duration and hyoid movement duration. The researchers involved in the analyses of the videofluoroscopy were blinded to age of the volunteers before the interpretation of the exams.

The statistical analysis was done by the Center of Quantitative Analysis of the Medical School of Ribeirão Preto USP (CEMEQ) using a linear model with mixed effects ${ }^{(22)}$. The results are reported as mean and standard deviation, unless otherwise stated. The differences were considered significant when $P \leq 0.05$ in a two tailed statistical analysis.

\section{RESULTS}

The duration of pharyngeal transit, pharyngeal clearance (Figure 1), UES opening, hyoid movement and oropharyngeal transit were longer in the younger group compared with the older group (Table 1). The results found for younger

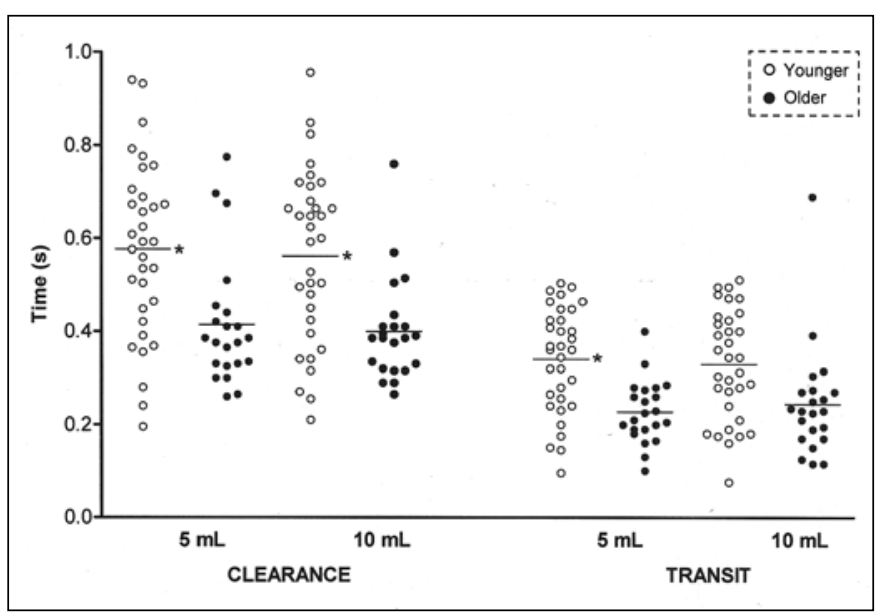

FIGURE 1. Duration of pharyngeal clearance and pharyngeal transit, in seconds, in younger and older subjects after swallows of $5 \mathrm{~mL}$ and $10 \mathrm{~mL}$ of a highly viscous liquid barium bolus. The horizontal bars represent the mean. $* P \leq 0.05$ vs older

TABLE 1 . Transit duration, in seconds, in younger $(\mathrm{n}=33)$ and older $(\mathrm{n}=22)$ subjects with swallows of $5 \mathrm{~mL}$ and $10 \mathrm{~mL}$ highly viscous liquid barium bolus. Mean (SD)

\begin{tabular}{lcccccc}
\hline & & $5 \mathrm{~mL}$ & & \multicolumn{1}{c}{$10 \mathrm{~mL}$} \\
Older & Younger & $\boldsymbol{P}$ value \\
\hline OT & Younger & Older & $\boldsymbol{P}$ value & $0.43(0.16)$ & $0.36(0.15)$ & 0.22 \\
PT & $0.59(0.32)$ & $0.49(0.34)$ & 0.17 & $0.33(0.12)$ & $0.25(0.12)$ & 0.06 \\
PC & $0.34(0.11)$ & $0.24(0.09)$ & 0.01 & $0.56(0.19)$ & $0.42(0.16)$ & 0.03 \\
UESO & $0.58(0.19)$ & $0.47(0.30)$ & 0.05 & $0.38(0.13)$ & $0.27(0.07)$ & 0.01 \\
HM & $0.33(0.11)$ & $0.25(0.10)$ & 0.01 & $0.78(0.29)$ & $0.49(0.13)$ & 0.01 \\
OPT & $0.85(0.29)$ & $0.57(0.22)$ & 0.01 & $0.79(0.21)$ & $0.61(0.22)$ & 0.02 \\
\hline
\end{tabular}

OT: oral transit; PT: pharyngeal transit; PC: pharyngeal clearance; UESO: upper esophageal sphincter opening; HM: hyoid movement; OPT: oropharyngeal transit 
TABLE 2. Transit duration, in seconds in younger $(n=16)$ and older $(n=15)$ men with swallows of a $5 \mathrm{~mL}$ and $10 \mathrm{~mL}$ highly viscous liquid barium bolus. Mean (SD)

\begin{tabular}{|c|c|c|c|c|c|c|}
\hline & \multicolumn{3}{|c|}{$5 \mathrm{~mL}$} & \multicolumn{3}{|c|}{$10 \mathrm{~mL}$} \\
\hline & Younger & Older & $P$ value & Younger & Older & $P$ value \\
\hline OT & $0.48(0.28)$ & $0.51(0.39)$ & 0.99 & $0.42(0.16)$ & $0.36(0.15)$ & 0.39 \\
\hline PT & $0.36(0.12)$ & $0.23(0.09)$ & 0.01 & $0.35(0.12)$ & $0.22(0.07)$ & 0.01 \\
\hline $\mathrm{PC}$ & $0.55(0.17)$ & $0.46(0.35)$ & 0.07 & $0.55(0.18)$ & $0.40(0.17)$ & 0.02 \\
\hline UESO & $0.32(0.11)$ & $0.26(0.11)$ & 0.09 & $0.37(0.11)$ & $0.26(0.06)$ & 0.01 \\
\hline HM & $0.92(0.29)$ & $0.60(0.23)$ & 0.01 & $0.92(0.30)$ & $0.50(0.12)$ & 0.01 \\
\hline OPT & $0.85(0.33)$ & $0.75(0.45)$ & 0.20 & $0.79(0.20)$ & $0.57(0.20)$ & 0.01 \\
\hline
\end{tabular}

OT: oral transit; PT: pharyngeal transit; PC: pharyngeal clearance; UESO: upper esophageal sphincter opening; HM: hyoid movement; OPT: oropharyngeal transit

TABLE 3. Transit duration, in seconds in younger $(n=17)$ and older $(n=7)$ women with swallows of a $5 \mathrm{~mL}$ and $10 \mathrm{~mL}$ highly viscous liquid barium bolus. Mean (SD)

\begin{tabular}{|c|c|c|c|c|c|c|}
\hline & \multicolumn{3}{|c|}{$5 \mathrm{~mL}$} & \multicolumn{3}{|c|}{$10 \mathrm{~mL}$} \\
\hline & Younger & Older & $P$ value & Younger & Older & $P$ value \\
\hline OT & $0.69(0.32)$ & $0.47(0.17)$ & 0.08 & $0.44(0.16)$ & $0.37(0.15)$ & 0.37 \\
\hline PT & $0.33(0.11)$ & $0.25(0.08)$ & 0.22 & $0.31(0.12)$ & $0.32(0.18)$ & 0.98 \\
\hline PC & $0.60(0.2)$ & $0.49(0.17)$ & 0.27 & $0.57(0.20)$ & $0.47(0.14)$ & 0.33 \\
\hline UESO & $0.34(0.12)$ & $0.24(0.09)$ & 0.05 & $0.38(0.14)$ & $0.28(0.09)$ & 0.04 \\
\hline $\mathrm{HM}$ & $0.77(0.28)$ & $0.49(0.18)$ & 0.01 & $0.65(0.21)$ & $0.46(0.16)$ & 0.08 \\
\hline OPT & $1.05(0.35)$ & $0.79(0.28)$ & 0.06 & $0.79(0.23)$ & $0.70(0.26)$ & 0.37 \\
\hline
\end{tabular}

OT: oral transit; PT: pharyngeal transit; PC: pharyngeal clearance; UESO: upper esophageal sphincter opening; HM: hyoid movement; OPT: oropharyngeal transit

men were longer oral-pharyngeal transit, hyoid movement, pharyngeal transit, pharyngeal clearance and UES opening compared to older men (Table 2). For women the difference observed was longer hyoid movement and longer UES opening duration in younger subjects (Table 3).

The relation between pharyngeal clearance duration and hyoid movement duration was similar in younger and older subjects, for $5 \mathrm{~mL}$ and $10 \mathrm{~mL}$ bolus volumes (Table 4).

TABLE 4. Relation between pharyngeal clearance duration/hyoid movement duration with swallows of a $5 \mathrm{~mL}$ and $10 \mathrm{~mL}$ highly viscous liquid barium bolus. Mean (SD)

\begin{tabular}{cccc}
\hline & Younger $(\mathrm{n}=33)$ & Older $(\mathrm{n}=22)$ & $\boldsymbol{P}$ value \\
\hline $5 \mathrm{~mL}$ & $0.72(0.32)$ & $0.84(0.29)$ & 0.14 \\
$10 \mathrm{~mL}$ & $0.77(0.26)$ & $0.86(0.31)$ & 0.21 \\
\hline
\end{tabular}

\section{DISCUSSION}

We found in this group of older subjects a lower mean of pharyngeal transit duration compared with the mean transit duration of younger subjects. This was an unexpected result which suggested adaptations of the swallowing to the effect of the progressive aging. The faster transit might be the consequence of a possible increase in pharyngeal contraction amplitude among the older subjects, seen with liquid and viscous bolus ${ }^{(28)}$, a fact that may be a compensation to the difficult in pharyngeal transit seen with progressive aging. Esophageal contraction amplitude increases between 40 to 60 years old, and is the same of young subjects after 60 years old ${ }^{(8,20)}$. Pharyngeal contraction amplitude is described as not influenced ${ }^{(19,30)}$ or increased ${ }^{(28)}$ by aging. Also, the pharyngeal intrabolus pressure, which may be associated with a possible decrease in pharyngeal compliance and elevated pharyngeal out flow resistance, is increased in the older population, another compensation to maintain a normal pharyngeal flow ${ }^{(24)}$, which is associated with the impairment of the UES opening ${ }^{(19,24)}$. An increase in pharyngeal contraction amplitude and in pharyngeal intrabolus pressure may be a way to sustain a safe transit duration and avoid the risk of aspiration inside the airway. With the progress of aging, this compensation may be not enough, increasing the pharyngeal transit duration and the risk of aspiration and pulmonary complications ${ }^{(16)}$. A recent investigation described that the tongue-pressure functional reserve does not decline in healthy aging ${ }^{(27)}$, with is another possibility to sustain a rapid pharyngeal transit before the evolution of the aging process cause the impairment of the pharyngeal transit.

Most of the studies which evaluated the pharyngeal transit in the elderly showed that the transit is longer than in younger subjects ${ }^{(12,13,15,19,24)}$. Increased slowness in movement is a general characteristic in aging ${ }^{(16)}$; however, these investigations had the participation of older subjects than we included in this. The swallowed barium has a 
high density, which causes a prolongation of the transit duration in normal subjects ${ }^{(3,26)}$, compared with swallows of low-density barium, but there are no results showing that these transit prolongations occur in old people as in young people. Although there was a superposition between the results of pharyngeal transit and clearance between the two age groups, the means of each one are different, raising the possibility that an increase in transit duration with the increase of barium density may happen in some younger subjects but not in older subjects. The aging process causes a progressive loss of pharyngeal and supraglottic sensitivity ${ }^{(1)}$, and loss of the swallowing reflex ${ }^{(7,23)}$, which suggests a possible no adaptation of the swallowing events, in older subjects, to the increase of bolus density, as seen in younger subjects ${ }^{(3,26)}$. The sensory regulation of swallowing is necessary for a normal deglutition ${ }^{(14)}$.

With the aging process, the UES pressure decreases ${ }^{(28,29)}$ and the sphincter has an opening impairment $t^{(16,24,28)}$. The pharyngeal efficiency has to improve to sustain the pharyngeal transit and avoid aspiration. This compensation may be insufficient with the progression of aging, putting the elderly subject at risk of aspiration. Older adults without neurological insults elicit more cortical involvement to complete the same swallowing tasks as younger adults ${ }^{(1)}$, suggesting that they need a more intense neurological activity to perform a safe swallow.

The duration of the pharyngeal transit in a healthy subject lasts approximately 1 second $^{(25)}$. As in older subjects pharyngeal swallow response to the bolus presence is delayed ${ }^{(11)}$, it is possible that the pharyngeal transit is shorter during the compensation period. With the progress of aging, this compensation is lost and the patients may have problems to swallow, more frequently with a higher bolus volume or a viscous bolus, and has an increase in residue amount in vallecula and/or at the UES ${ }^{(11)}$.

Swallowing apnea duration during saliva swallowing increases with aging in women but not in men ${ }^{(9)}$, which suggested the possibility that a gender effect may have interaction with an age effect. As we have a predominance of males in the older group and not in the young group, the composition of the population evaluated might have influence on the results. We demonstrated that in men the events associated with swallowing are shorter in older than in younger men. The described effect of the aging process seems to be more intense in men than in women.

Although some differences were observed between younger and older groups, the relation between pharyngeal clearance and hyoid movement duration is similar in both groups, one more indication that there is a swallow adaptation to sustain safe swallows, at least before 70 years. Normal aging does not influence pharyngo-UES coordination ${ }^{(30)}$.

There are some limitations in this investigation. The proportion of the number of men and women is not the same in the younger and older group, the evaluation was performed with only one consistency and both groups have a large age distribution.

In conclusion, a highly viscous liquid bolus crosses the pharynx faster in older subjects (56-77 years old) than in younger subjects (19-55 years old).

\section{Author contribution}

Nascimento WV, Santos CM, Cassiani RA, Dantas RD who had participation in the planning, in the investigation and in the preparation of the manuscript.

Nascimento WV, Santos CM, Cassiani RA, Dantas RD. Influência da idade na deglutição de bolo líquido com alta viscosidade. Arq Gastroenterol. 2015,52(1):32-6

RESUMO - Contexto - A função de deglutição tem um declínio com o envelhecimento, principalmente em pessoas com mais de 80 anos de idade. Na população com mais de 69 anos cerca de $11 \%$ dos indivíduos relatam sintomas indicativos de disfagia. Objetivo-O nosso objetivo foi avaliar a hipótese de que o indivíduo assintomático antes dos 80 anos de idade tem compensações que mantém deglutição segura e eficiente, pelo menos com deglutição de líquido. Método - Foi realizada avaliação videofluoroscópica da deglutição em 55 voluntários normais, um grupo mais jovem, com 33 indivíduos (16 homens e 17 mulheres) com idades entre 19-55 anos, média de 35,5 \pm 9,8 anos e um grupo mais velho, com 22 indivíduos (15 homens e 7 mulheres) com idades entre 56-77 anos, média de 64,8 \pm 6,8 anos. Os indivíduos ingeriram, em duplicata, $5 \mathrm{~mL}$ e $10 \mathrm{~mL}$ de sulfato de bário líquido, com pH de 7,9, densidade de $1,82 \mathrm{~g} / \mathrm{cm}^{3}$, e viscosidade de $895 \mathrm{cp}$. Resultados - A duração média do trânsito faríngeo, da depuração da faringe, da abertura do esfíncter superior do esôfago, do movimento do osso hióide e do trânsito oro-faríngeo foi mais longa no grupo mais jovem em comparação com o grupo mais velho. A relação entre a duração da depuração da faringe e duração do movimento do osso hióide foi semelhante em indivíduos mais jovens e mais velhos, com os volumes de $5 \mathrm{~mL}$ e $10 \mathrm{~mL}$. Conclusão - Em média, um bolo líquido altamente viscoso atravessa a faringe mais rápido em indivíduos mais velhos (56-77 anos de idade) do que em indivíduos mais jovens (19-55 anos de idade), o que sugere uma adaptação ao processo de envelhecimento para manter uma deglutição segura.

DESCRITORES - Transtornos de deglutição. Faringe. Efeito idade. Peristaltismo. Viscosidade. 


\section{REFERENCES}

1. Aviv JE, Martin JH, Jones ME, Wee TA, Diamond B, Keen MS, Blitzer A. Age-related changes in pharyngeal and supraglottic sensation. Ann Otol Rhinol Laryngol. 1994;103(10):749-52.

2. Cook IJ, Weltman MD, Wallace K, Shaw DW, McKay E, Smart RC, Butler SP. Influence of aging on oral-pharyngeal bolus transit and clearance during swallowing: scintigraphic study. Am J Physiol. 1994;266(6 Pt 1):G972-7.

3. Dantas RO, Dodds WJ, Massey BT, Kern MK. The effect of high vs low-density barium preparations on the quantitative features of swallowing. AJR Am J Roentgenol. 1989;153(6):1191-5.

4. Dantas RO, Alves LMT, Dalmazo J, Santos CM, Cassiani RA, Nascimento WV. Effect of age on proximal esophageal response to swallowing. Arq Gastroenterol. 2010;47(4):339-42.

5. Dua K, Surapanemi SN, Kuribayashi S, Hafeezullah M, Shaker R. Effect of aging on hypopharyngeal safe volume and aerodigestive reflexes protecting the airways. Laryngoscope. 2014;124(8):1862-8.

6. Dodds WJ, Taylor AJ, Stewart ET, Kern MK, Logemann JA, Cook IJ. Tipper and dipper types of oral swallows. AJR Am J Roentgenol. 1989;153(6):1197-9.

7. Ebihara S, Ebihara T, Kohzuki M. Effect of aging on cough and swallowing reflexes: implications for preventing aspiration pneumonia. Lung. 2013; 190:29-33.

8. Ferriolli E, Dantas RO, Oliveira RB, Braga FJHN. The influence of ageing on oesophageal motility after ingestion of liquids with different viscosities. Eur $\mathbf{J}$ Gastroenterol Hepatol. 1996;8(8):793-8.

9. Hiss SG, Treole K, Stuart A. Effects of age, gender, bolus volume, and trial on swallowing apnea duration and swallow/respiratory phase relationships of normal adults. Dysphagia. 2001;16(2):128-35.

10. Holland G, Jayasekeran V, Pendleton N, Horan M, Jones M, Handy S. Prevalence and symptom profiling of oropharyngeal dysphagia in a community dwelling of an elderly population: a self reporting questionnaire survey. Dis Esophagus. 2011;24(7):476-80

11. Humbert IA, Fitzgerald ME, McLaren DG, Johnson S, Porcaro E, Kosmatka $\mathrm{K}$, Hind J, Robbins J. Neurophysiology of swallowing: effects of age and bolus type. Neuroimage. 2009;44(3):982-91.

12. Humbert IA, Robbins J. Dysphagia in the elderly. Phys Med Rehabil Clin N Am. 2008;19(4):853-66.

13. Im I, Kim Y, Oommen E, Kim H, Ko MH. The effect of bolus consistency in pharyngeal transit duration during normal swallowing. Ann Rehabil Med. 2012;36(2):220-5

14. Jafari S, Prince RA, Kim DY, Paydarfar D. Sensory regulation of swallowing and airway protection: a role for the internal superior laryngeal nerve in humans. $J$ Physiol. 2003; 550(Pt 1):287-304.

15. Kendall KA, Leonard RJ. Bolus transit and airway protection coordination in older dysphagic patients. Laryngoscope. 2001;111(11 Pt 1):2017-21.
16. Logemann JA, Curro FA, Pauloski B, Gensler G. Aging effects on oropharyngeal swallow and the role of dental care in oropharyngeal dysphagia. Oral Dis. 2013;19(8):733-7.

17. Logemann JA, Pauloski BR, Rademaker AW, Colangelo LA, Kahrilas PJ, Smith $\mathrm{CH}$. Temporal and biomechanical characteristics of oropharyngeal swallow in younger and older men. J Speech Lang Hear Res. 2000;43(5):1264-74.

18. Logemann JA, Pauloski BR, Rademaker AW, Kahrilas PJ. Oropharyngeal swallow in younger and older women: videofluoroscopic analysis. J Speech Lang Hear Res. 2002;45(3):434-44

19. Omari TI, Kritas S, Cock C, Besanko L, Burgstad C, Thompson A, Rommel N, Heddle R, Fraser RJL. Swallowing dysfunction in healthy older people using pharyngeal pressure-flow analysis. Neurogastroenterol Motil. 2014;26(1):59-68.

20. Richter JE, Wu WC, Johns DN, Blackwell JN, Nelson III JL, Castell JA, Castell DO. Esophageal manometry in 95 healthy adult volunteers. Variability of pressures with age and frequency of "abnormal contractions". Dig Dis Sci. 1987;32(6):583-92.

21. Robins J, Hamilton J, Lof GL, Kempster GB. Oropharyngeal swallowing in normal adults of different ages. Gastroenterology. 1992;103(3):823-9.

22. Schall R. Estimation in generalized linear models with random effects. Biometrika. 1991;78:719-27.

23. Shaker R, Ren J, Zamir Z, Sarna A, Liu J, Sui Z. Effect of aging, position, and temperature on the threshold volume triggering pharyngeal swallows. Gastroenterology. 1994;107(2):396-402.

24. Shaw DW, Cook IJ, Gabb M, Holloway RH, Simula ME, Panagopoulos V, Dent J. Influence of normal aging on oral-pharyngeal and upper esophageal sphincter function during swallowing. Am J Physiol. 1995;268 (3 Pt 1):G389-96.

25. Shaw SM, Martino M. The normal swallow. Muscular and neurophysiological control. Otolaryngol Clin N Am. 2013;46(6):937-56.

26. Sokely SL, Molfenter SM, Steele CM. Effects of barium concentration on oropharyngeal swallow timing measures. Dysphagia. 2014;29(1):78-82.

27. Steele CM. Optimal approaches for measuring tongue-pressure functional reserve. J Aging Res. 2013;2013:542909.

28. van Hervaarden MA, Katz PO, Gideon M, Barrett J, Castell JA, Achem S, Castel DO. Are manometric parameters of the upper esophageal sphincter and pharynx affected by age and gender? Dysphagia. 2003;18(3):211-7.

29. Weihrauch TR, Vallerius P, Alpers H. Assessment of various factors influencing esophageal pressure measurements. II. Significance of physiological factors in intraluminal manometry. Klin Wochenschr. 1980;58(6):287-92.

30. Yokoyama M, Mitomi N, Tetsuka K, Tayama N, Niimi S. Role of laryngeal movement and effect of aging on swallowing pressure in the pharynx and upper esophageal sphincter. Layngoscope. 2000;110(3 Pt 1):434-9.

Received 2/7/2014 Accepted 29/8/2014 